\title{
Age, Growth, Mortality and Reproduction Biology of the Black Seabream, Spondyliosoma cantharus in North Aegean Sea, Turkey, Mediterranean Basin
}

\author{
İsmail Burak Daban ${ }^{1, *}$ (i) \\ ${ }^{1}$ Çanakkale Onsekiz Mart University, Marine Science and Technology Faculty, 17100, Canakkale, Turkey
}

\section{How to cite}

Daban, I.B. (2022). Age, Growth, Mortality and Reproduction Biology of the Black Seabream, Spondyliosoma cantharus in North Aegean Sea, Turkey, Mediterranean Basin. Turkish Journal of Fisheries and Aquatic Sciences, 22(4), TRJFAS21016. http://doi.org/10.4194/TRJFAS21016

\section{Article History \\ Received 22 November 2021 \\ Accepted 02 March 2022 \\ First Online 04 March 2022 \\ Corresponding Author \\ Tel.: +05344363342 \\ E-mail: burakdaban@gmail.com}

\author{
Keywords \\ Growth \\ Mortality \\ Spawning \\ Fecundity \\ Spondyliosoma cantharus
}

\begin{abstract}
In the present study, the population parameters (length-length and length-weight relationships, age, growth, mortality) and reproductive biology (sex ratio, GSI, condition, length at first maturity, spawning period, fecundity) of black seabream (Spondyliosoma cantharus Linnaeus, 1758) were investigated. The length-length relationship and length-weight relationship were calculated as $\mathrm{FL}=0.911 \mathrm{TL}-0.0433$ and $W=0.0123 T L^{3.0614}\left(R^{2}=0.97\right)$, respectively. Parameters of the von Bertalanffy growth equation were: $L_{\infty}=33.21 \mathrm{~cm}, K=0.21$ per year, $t_{0}=-1.84$ year and age varied between 0 and 8 years. The instantaneous rates of total mortality (Z) and natural mortality (M) were 0.64 and 0.47 per year, respectively. Rates for fishing mortality (F) and exploitation (E) were 0.17 and 0.27 per year, respectively. The spawning season extended from February to May and peaked in March and April. The female/male ratio was found to be 3.49/1 and sex inversion from female to male occurred after the 24 $\mathrm{cm}$ TL length group. Total lengths at $50 \%$ maturity were $22.25 \mathrm{~cm}$ for males and 20.59 $\mathrm{cm}$ for females. The mean absolute fecundity (F) was $109,457 \pm 8,011$ oocytes, ranging from 59,666 to 182,589 .
\end{abstract}

\section{Introduction}

Sparidae is a family of the order Perciformes and contains 164 species in 38 genera (Eschmeyer's Catalog of Fishes, 2020). Recently, the sister family Centracanthidae (picarels) was merged with the Sparidae (Santini et al., 2014), while they were previously listed as distinct and separate (Nelson, 2006; Golani et al., 2006; Mater et al., 2011). As far as known, 24 Sparidae species within 13 genera (Boops, Centracanthus, Dentex, Diplodus, Evynnis, Lithognathus, Oblada, Pagellus, Pagrus, Sarpa, Sparus, Spicara and Spondyliosoma) were reported from Turkish territorial waters (Mater et al., 2011). There are two more species (Crenidens and Rhabdosargus haffara) in the Eastern
Mediterranean (Golani et al., 2006) which are lessepsian (Paruğ \& Cengiz, 2020). Among the teleost fish commonly distributed in the littoral zone, Sparidae are one of the most important taxa around the entire Mediterranean, except the Baltic Sea, with high economical value, wide range of distribution and being able to be caught with various fishing gear.

According to the General Fisheries Commission for the Mediterranean (GFCM), 83\% of the total fishing fleet consists of small-scale vessels, especially around the central and eastern Mediterranean and Black Sea. In the Eastern Mediterranean and Black Sea, 87.600 fishing vessels are registered legally; 21,425 of which belong to small-scale fisheries. Among the countries operating in GFCM area, Turkey is a major producer of 273.977 tons 
(23.3\%) of the total catch (GFCM, 2020). Small-scale fisheries, such as gillnet, trammel net, handline and longline, operating in Turkey target mostly Sparidae fish species.

Black seabream, Spondyliosoma cantharus (Linnaeus, 1758), is defined as a marine, benthopelagic and subtropical fish species (Riede, 2004) which has a wide distribution range from Scandinavia to northern Namibia (Heemstra, 1995), including the Strait of Gibraltar, Mediterranean and the Black Sea, Madeira, Canary Islands, and Cape Verde (Bauchot \& Hureau, 1990). It mostly found on seagrass beds and rocky and sandy habitats up to $300 \mathrm{~m}$ depth and the feeding type was identified as omnivorous (Bauchot \& Hureau, 1990). S. cantharus is known as a single Sparidae species, which has demersal eggs. Sex reversal in consequence of progynic hermaphroditism occurs at approximately 24.3 cm TL (Boughamou et al., 2015). Great fishing pressure on the stocks is known and the species was assessed as LC (least concern) status (Nieto et al., 2015; IUCN, 2020).

S. cantharus is distributed in all the seas of Turkey and is included in the fish fauna of the Levantine coasts (Başusta \& Erdem, 2000; Keskin et al., 2011; Saad, 2005) and Northern Aegean Sea (Keskin \& Ünsal, 1998; Torcu \& Aka, 2000; Eryılmaz, 2003; Cengiz et al., 2011; Cengiz et al., 2012; Çoker \& Akyol, 2018). Although it is mentioned in the Black Sea fish fauna (Keskin, 2010), it was not included in the benthic fish fauna of the western Black Sea (Yıldız et al., 2019), central Black Sea (Gönener \& Özdemir, 2012) and eastern Black Sea (Ak et al., 2008; Ak et al., 2011).

Knowledge about population and reproductive biology including age, growth, mortality, sex ratio, sexual maturity, spawning season and fecundity is a major component of fisheries management due to providing important data for stock status and structure (Marshall, 2009). For implementation and enforcement of management rules and issues, managers firstly need qualified scientific and statistical data (O'Brien, 2009). Some valuable studies were conducted on population and reproduction biology of $S$. cantharus around the Canary Islands (Pajuelo \& Lorenzo, 1999), Algeria (Boughamou et al., 2015), Tunisian coast (MouineQueslati et al., 2015), Adriatic (Dulcic \& Kraljevic, 1996; Dulcic et al., 1998) and southwestern Portugal (Gonçalves \& Erzini, 2000). However, no scientific study was found in the eastern Mediterranean, Aegean Sea and Turkish territorial waters.

Thus, the aim of the present study was to determine the first results about age, growth, mortality, reproduction and fecundity of $S$. cantharus around the North Aegean Sea, eastern Mediterranean.

\section{Materials and Methods}

The northern Aegean coasts of Turkey are divided into sub-regions of Saros Bay, Gallipoli Peninsula, Gökçeada Island, Bozcaada Island, and Edremit Bay (Cengiz \& Paruğ, 2021) and these are known to be important fishing areas with many commercial fishing ports and small-scale fishery vessels. The area has great biodiversity due to the various coastal types such as sandy, rocky and vegetated (Gönülal \& Güreşen, 2014). In the present study, specimens from Gökçeada Island, North Aegean Sea (Figure 1), were obtained from smallscale handline and longline fishermen with random sampling between August 2020 and July 2021.

In total, 355 individuals were sampled, total length (TL) and fork length (FL) were measured to the nearest $\mathrm{mm}$, and total weight and gonad weight were recorded

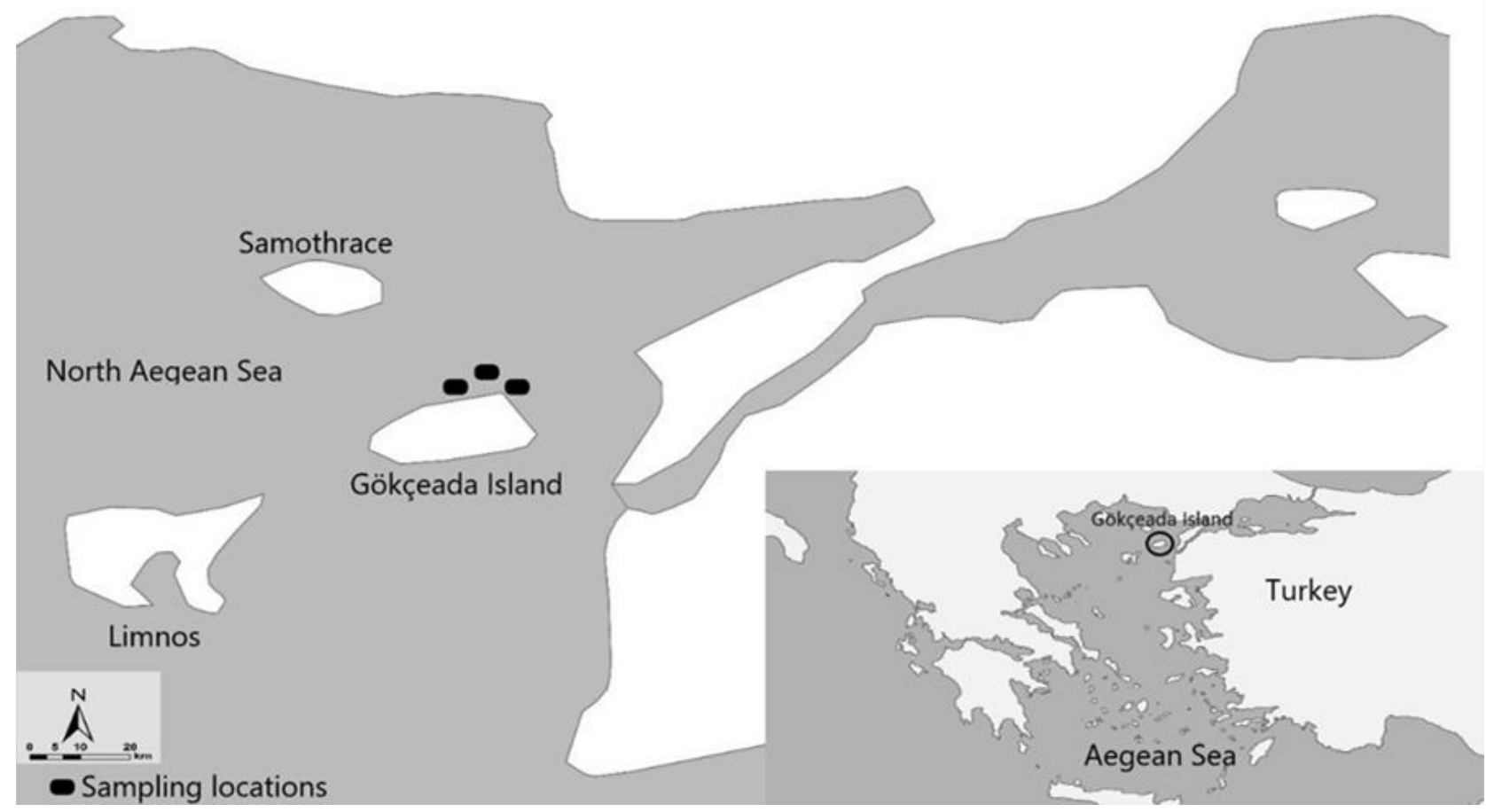

Figure 1. Study area and sampling locations 
to the nearest $\mathrm{g}$ with precision scales. Sex and the 5staged maturity scale (Holden and Raitt, 1974) were determined by macroscopic observation of male and female gonads. Sexual inversion length was estimated by aggregating the length frequency distribution where females and males overlap (Shapiro, 1984; Gonçalves \& Erzini, 2000).

As described by Ricker (1975), the length-weight relationship was estimated by the exponential regression $\mathrm{W}=a^{*} T L^{b}$, where $\mathrm{W}$ is the total weight $(\mathrm{g})$ and $T L$ is the total length $(\mathrm{cm})$. The constants $a$ and $b$ were estimated by least square linear regression after log transformation. Growth type was determined by the $t$ test of the value " $b$ " that reflects allometry of growth. To test for possible significant difference between sexes, the Student's t-test was used for comparison of the slopes (Zar, 1996).

Age was estimated by interpreting annual growth rings of scales belonging to 355 black seabream specimens. Scales from the back of the pectoral fin were removed, cleaned with $4 \% \mathrm{KOH}$ solution, then rinsed with distilled water and subsequently put in $96 \%$ alcohol for 15-20 $\mathrm{min}$ and stored dry in individually labelled eppendorf tubes. They mounted between glass slides for determining age by interpreting growth rings. Readings were made by three independent researchers. Scales from the back of the pectoral fin were removed and cleaned to determine age by interpreting growth rings. Measurements were always made along the longest axis of the scale. Growth parameters were estimated for the whole population (both sexes together), for males and for females using the von Bertalanffy growth equation (von Bertalanffy, 1938):

$$
L(t)=L_{\infty} \quad\left[1-\exp \left(-k\left(t-t_{0}\right)\right)\right.
$$

where $L(t)$ is total length at time $t, L_{\infty}$ is the asymptotic length $(\mathrm{cm}), \mathrm{K}$ is the growth coefficient $\left(\mathrm{t}^{-1}\right)$ and to is the hypothetical age when the size of the fish is zero. Growth parameters were estimated using the FAO-

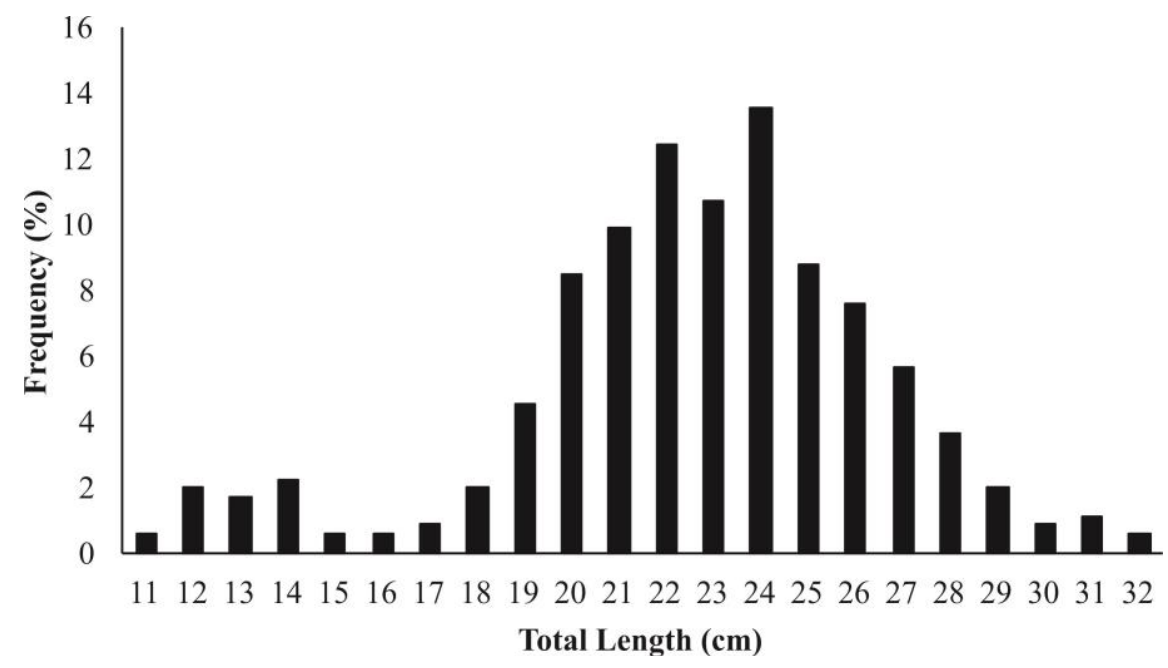

Figure 2. Length - frequency distribution of the Black Seabream, Spondyliosoma cantharus.

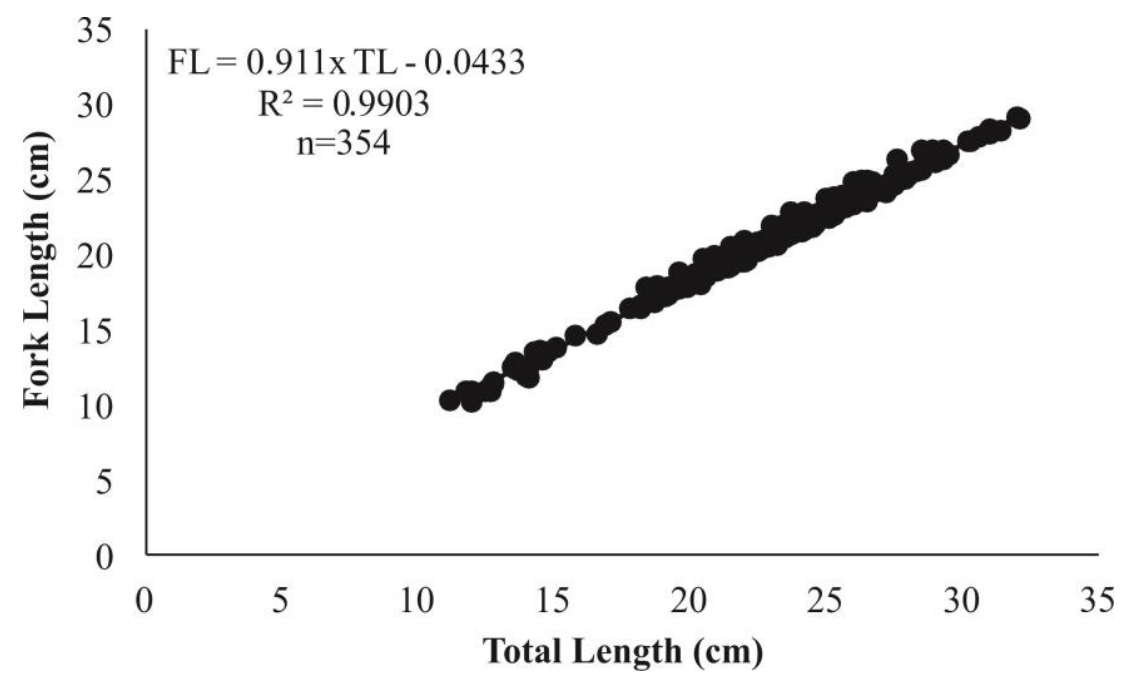

Figure 3. The total length $(\mathrm{TL})$ - fork length $(\mathrm{FL})$ relationship of the Black Seabream, Spondyliosoma cantharus. 
ICLARM Stock Assessment Tool (FISAT II) software (Gayanilo et al., 2005). The growth parameters obtained in this study were compared with the parameters obtained in other studies from various geographical areas using the growth performance index $(\varphi)$ (Pauly \& Munro 1984).

Instantaneous total mortality (Z) was calculated with a length-converted catch curve using Pauly's method (Pauly, 1984). Natural mortality (M) was determined using Pauly's (1980) empirical formula which includes von Bertalanffy growth parameters and mean annual sea water temperature $\left(15.7^{\circ} \mathrm{C}\right.$; Türkoğlu, 2010). Fishing mortality was calculated as the deduction of natural mortality (M) from total mortality (Z) (Bingel, 2002). The exploitation rate (E) was obtained using Gulland's (1979) formula, E=F/Z.

Spawning season of the species was estimated by evaluation of sexual maturity stages and gonadosomatic index (GSI). GSI was calculated according to Gibson and
Ezzi (Gibson \& Ezzi, 1980). For both sexes, length at first maturity ( $\left.L_{50}\right)$ was estimated from the individuals collected during the spawning period with using the least square method (King, 1995).

Black seabream is known as an indeterminate spawner due to varied oocyte size classes being continuously distributed in the ovary. The size at which $50 \%$ oocytes showed vacuolation (Macer, 1974) was found to be $500 \mu \mathrm{m}$ by Dulcic et al. (1998) for black seabream. A calculation of small sized non-vacuolated oocytes increases the error margin due to exposure to more physical damage, resulting in more counts and miscalculations (Balgueras et al.,1993). For the reasons explained, in this study, oocytes larger than $500 \mu \mathrm{m}$ were used for fecundity calculations, as described by Balgueras et al. (1993). After the microscopic examination, the gonads containing eggs with a diameter larger than $500 \mu \mathrm{m}$ were determined as mature. Thus, 19 ovaries meeting this criterion were
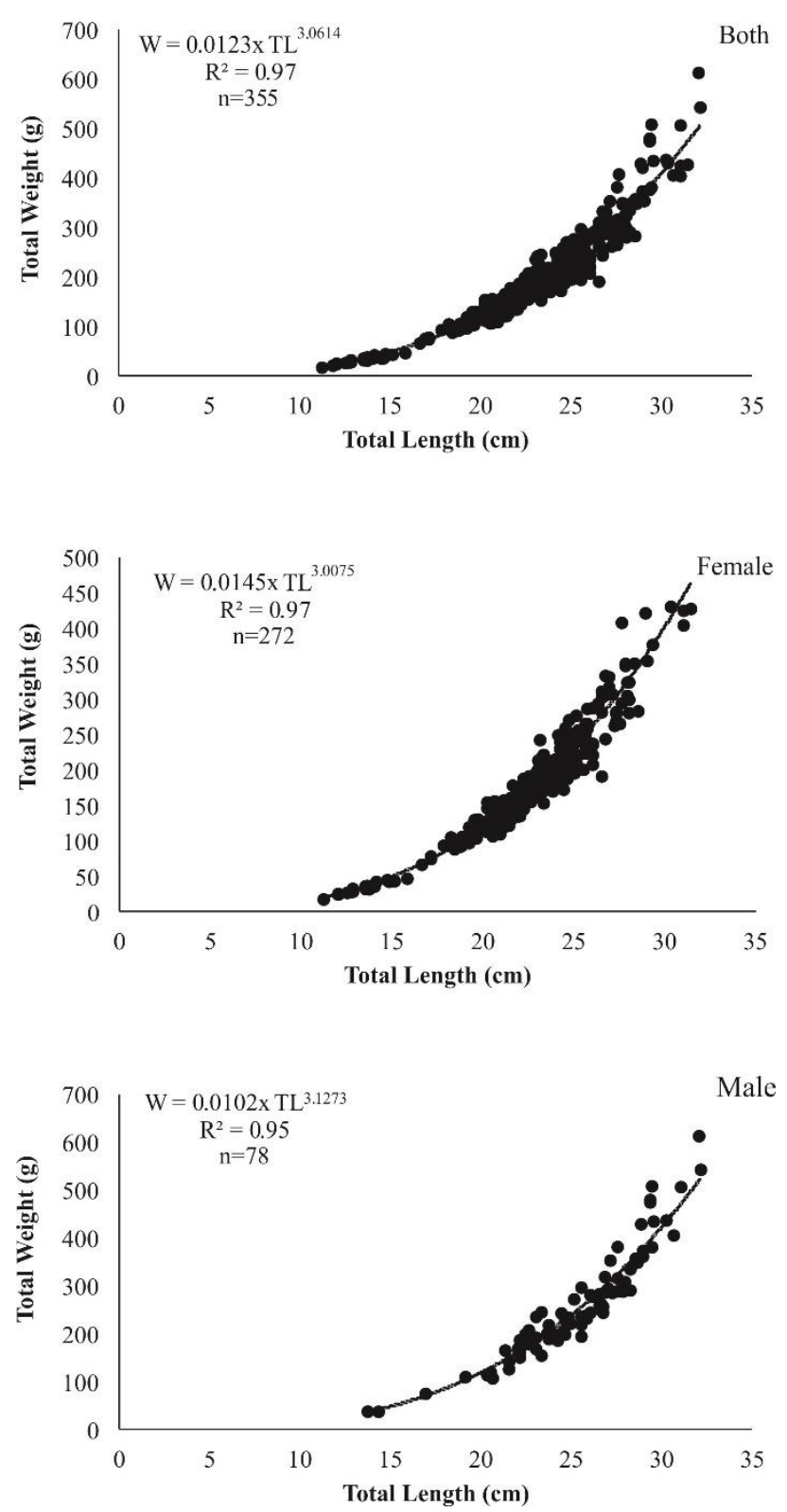

Figure 4. The total length (TL) - weight relationship of the Black Seabream, Spondyliosoma cantharus. 
included in absolute fecundity analyses. The individuals with mature ovaries ranged between $20.4 \mathrm{~cm}$ and 26.7 $\mathrm{cm}$ TL in length, $136.12 \mathrm{~g}$ and $333.83 \mathrm{~g}$ in weight and 2 to 6 in age.

For fecundity estimates, the gravimetric method was used (Bagenal, 1978). In order to calculate absolute fecundity, a subsample of $0.05 \mathrm{~g}$ from 3 parts (anterior, mid and posterior parts) were taken from each ovary. These subsamples were weighed and mature oocytes were counted three times under a stereozoom microscope. The subsample fecundity was determined according to Yeldan and Avşar's (2000) formula; $F_{1}=\left(W_{g} \times N\right) \times W_{s}^{-1}$, where $F_{1}$ is the total number of eggs in the ovary sub-sample, $\mathrm{Wg}$ is the gonad weight, $\mathrm{N}$ is the number of eggs in the sub-sample, and Ws is subsample weight. Finally, absolute fecundity, which is the number of mature oocytes spawned by a female in a single spawning, was determined by averaging the total number of eggs in each ovary subsample (F1, F2 and F3).
The total length-fecundity, total weight-fecundity and age-fecundity relationships were estimated for females using linear and exponential regression to determine which equations fit best.

\section{Results}

\section{Population Parameters}

Specimens ranged from $11.2 \mathrm{~cm}$ TL to $32.1 \mathrm{~cm} \mathrm{TL}$ and $10.2 \mathrm{~cm}$ FL to $29.1 \mathrm{~cm} \mathrm{FL}$, weighing from $11.43 \mathrm{~g}$ to $613.73 \mathrm{~g}$, total weight (TW). The mean TL, FL and TW of the whole population were $23.03 \pm 0.21 \mathrm{~cm} \mathrm{TL}$, $20.93 \pm 0.19 \mathrm{~cm}$ FL and $199.31 \pm 5.10 \mathrm{~g}$, respectively. The total length of males ranged between $13.7 \mathrm{~cm}$ and 32.1 $\mathrm{cm}$ (mean: $25.22 \pm 0.40 \mathrm{~cm} \mathrm{TL}$ ), and their weight between $39.36 \mathrm{~g}$ and $613.73 \mathrm{~g}$ (mean: $213.35 \pm 7.57 \mathrm{~g}$ ), whereas females ranged between $11.2 \mathrm{~cm}$ and $31.4 \mathrm{~cm}$ (mean: $22.50 \pm 0.20 \mathrm{~cm} \mathrm{TL}$ ) in length, and $11.43 \mathrm{~g}$ and $431.1 \mathrm{~g}$
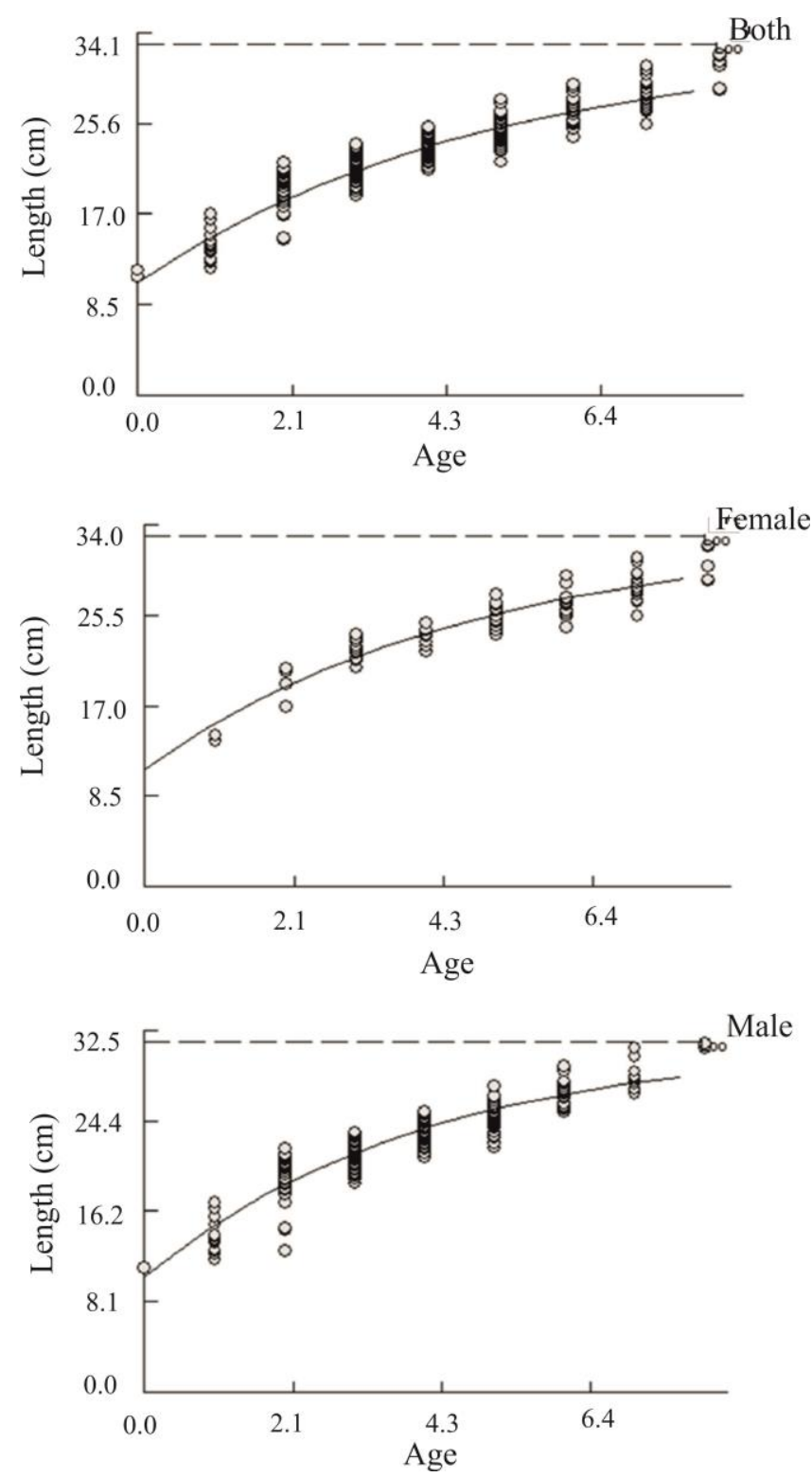

Figure 5. The growth parameters of Von Bertalanffy fitted to back calculated size at age data that estimated with FISAT II in the Black Seabream, Spondyliosoma cantharus 
(mean: $183.11 \pm 4.87 \mathrm{~g}$ ), in weight. The mean lengths (Mann-Whitney test: U: 5997, $\mathrm{p}<0.0001$ ) and weights (Mann-Whitney test: U: 5864, $\mathrm{p}<0.0001$ ) of males and females were significantly different. According to monthly variations of length distribution, the largest sized individual $(32.1 \mathrm{~cm} \mathrm{TL}$ ) was observed in March, whereas the smallest specimen was obtained in May (11.2 cm TL). The highest mean TL was found in June $(24.8 \pm 0.3 \mathrm{~cm} \mathrm{TL})$ and lowest mean TL was observed in May $(18.1 \pm 0.4 \mathrm{~cm} \mathrm{TL})$.

According to the length - frequency distribution (Figure 2), the common length group was determined as $24 \mathrm{~cm} \mathrm{TL}$ (13.5\%) with $38.6 \%$ of the population in the 22 and $24 \mathrm{~cm}$ TL length groups. It was observed that smaller length groups (11-16 cm TL) were represented by limited specimens due to the data set comprising commercial longline catch.

The total length-fork length regressions indicated a strong linear relationship $\left(r^{2}=0.99 ; n=355\right)$ with the formula $F L=0.911 * T L-0.0433$ (Figure 3). The lengthweight relationship was calculated as $\mathrm{W}=0.0145 * \mathrm{~L}^{3.0075}$ $\left(r^{2}=0.97\right)$ for females, $W=0.0102 * L^{3.1273}\left(r^{2}=0.95\right)$ for males and $W=0.0123^{*} T^{3.0614}\left(r^{2}=0.97\right)$ for both sexes (Figure 4). The length-weight regressions indicated positive allometric growth in males and the whole population, whereas females had isometric growth (Table 1).

\section{Age, Growth and Mortality}

Measurements of 355 scales showed that the age distribution of the sampled individuals varied between 0 and 8 . Table 2 shows the length-age distribution of the 355 individuals. The peak age distribution was observed in age group 3 including $24.6 \%$ of the individuals. The majority of individuals (61.1\%) ranged in age between 3 and 5 . The growth parameters of von Bertalanffy fitted to back-calculated size with age data were $L_{\infty}=33.21 \mathrm{~cm}$ $\mathrm{TL}, \mathrm{K}=0.21$ and $\mathrm{t}_{0}=-1.84$ per year for all individuals, $\mathrm{L}_{\infty}=32.9 \mathrm{~cm}$ TL, $K=0.22$ and $\mathrm{t}_{0}=-1.83$ per year for females and $L_{\infty}=31.49 \mathrm{~cm} \mathrm{TL}, K=0.25$ and $t_{0}=-1.59$ per year for males (Figure 5). The growth performance index $\left(\varphi^{\prime}\right)$ was

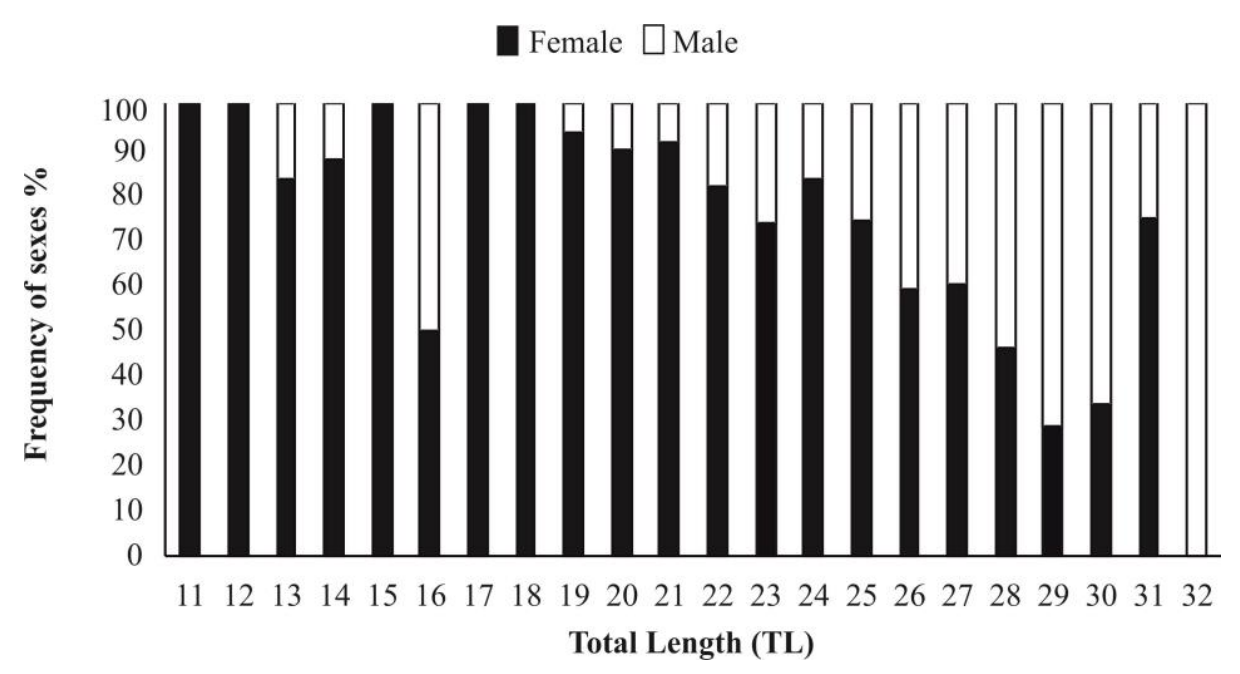

Figure 6. The sex reversal of the Black Seabream, Spondyliosoma cantharus according to length.

$\square$ Male $\quad$ Female $\quad$ All Individuals

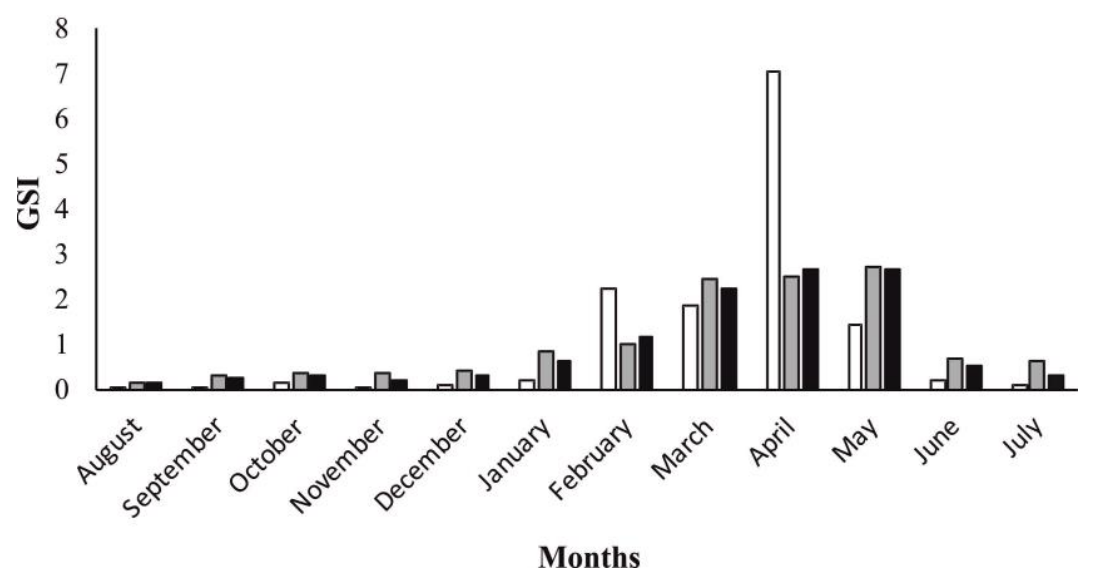

Figure 7. Temporal variations of the gonadosomatic Index (GSI) of the Black Seabream, Spondyliosoma cantharus 
2.3648. For all individuals, instantaneous total mortality $(\mathrm{Z})$ and natural mortality $(\mathrm{M})$ were determined as 0.64 and 0.47 per year, respectively. The fishing mortality (F) was calculated as 0.17 per year and exploitation rate $(E)$ was 0.27 per year.

\section{Reproductive Biology}

Of all specimens examined, 272 (77.7\%) were females and $78(22.3 \%)$ were males. The sex of the remaining 5 fish could not be identified macroscopically because they were immature with very thin and translucent gonads. Thus, the overall ratio of female to male was determined as 3.49:1 ( $\chi 2$ test, $p<0,05, N=350$ ). The sex ratio were statistically different in April and May compared to other months due to the disappearance of male individuals. Females predominated in smaller size intervals and males had larger sizes. The males dominated the $28 \mathrm{~cm} \mathrm{TL}$ and larger length groups with $71 \%$ of total individual number. The sexes of two individuals larger than $32 \mathrm{~cm}$ TL were male. The sex reversal occurred after $24 \mathrm{~cm}$ TL (Figure 6).

Highest condition factor (CF) values were determined in February and March for males and October for females. The minimum gonadosomatic index (GSI) values were observed between June and December for males, females and all individuals, whereas the highest monthly GSI values were found between March and May for females and April for males (Figure 7). Mature gonads (4th stage) were found between February and May for males. The greatest number of mature females were observed in March and April (Figure 8). According to the CF, GSI values and the timing of mature individuals, the spawning season of $S$. cantharus was estimated to be between February and May, peaking from March to April. First sexual maturity
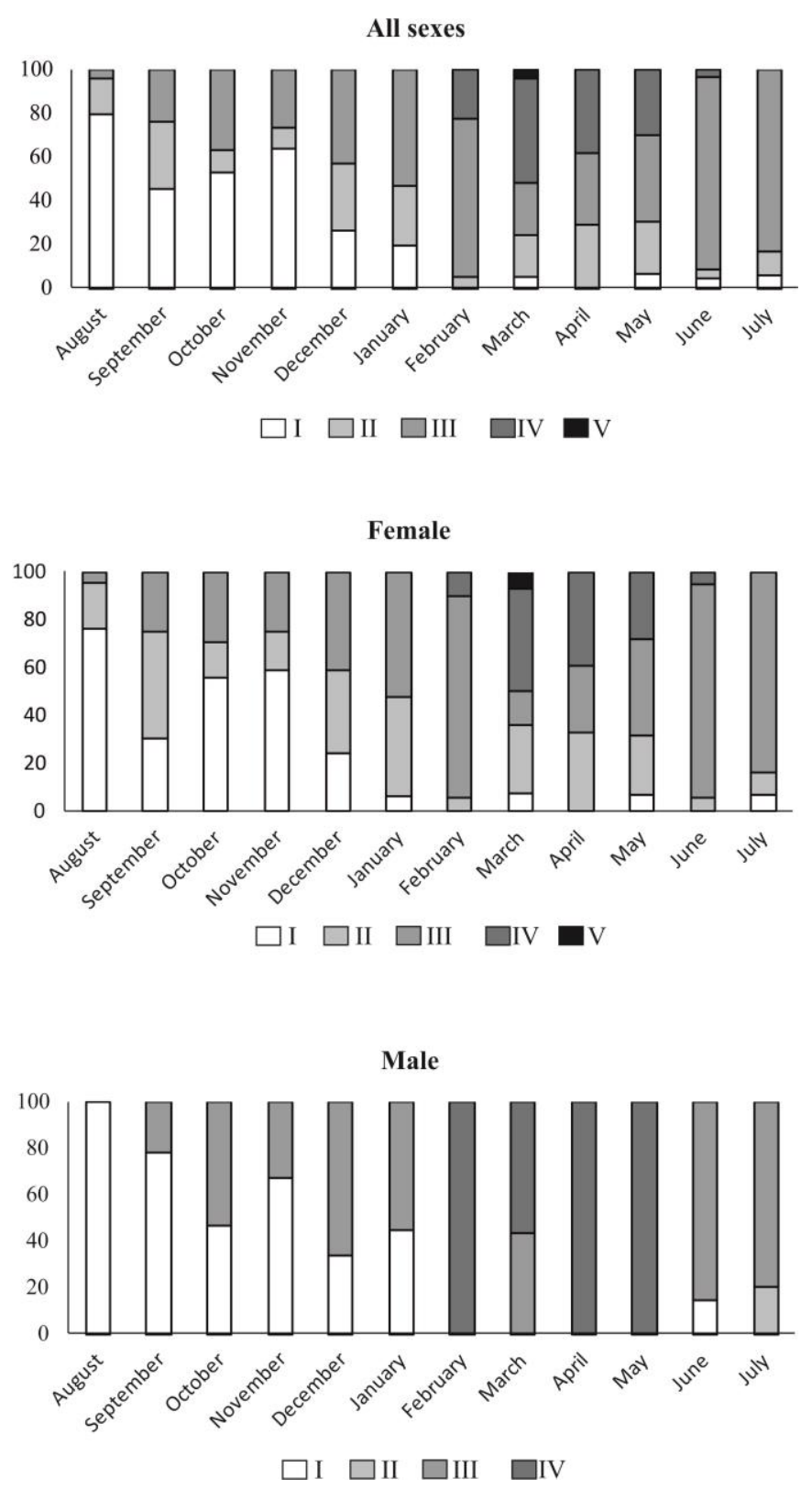

Figure 8. Monthly percentage of each maturity stage for males, females and all sexes of Northern Aegean Sea population of the Black Seabream, Spondyliosoma cantharus. I: Immature, II: Maturing, III: Mature, IV: Spawning, V: Post-Spawning 
length was determined as $22.25 \mathrm{~cm}$ TL for males and $20.59 \mathrm{~cm}$ TL for females.

In total, absolute fecundity of black seabream ranged from 59,666 to 182,589 , with a mean of $109,457 \pm 8,011$. Linear relationships were found between absolute fecundity - total length ( $F=15912 \mathrm{TL}$ 273828; $\left.r^{2}=0.73\right)$, absolute fecundity - total weight ( $\left.F=593.91 T W-25705 ; r^{2}=0.86\right)$ and absolute fecundity age $\left(F=26271 t+1624.5 ; r^{2}=0.77\right)$ (Figure 9).

\section{Discussion}

As in many Sparidae fish species, strong linear relationships were found between the total length and fork length. The results for length-weight relationship and growth type of black seabream are summarized and compared in Table 3. Positive allometric growth was found in 8 of 15 studies, which included rather different geographical areas. Although the eastern
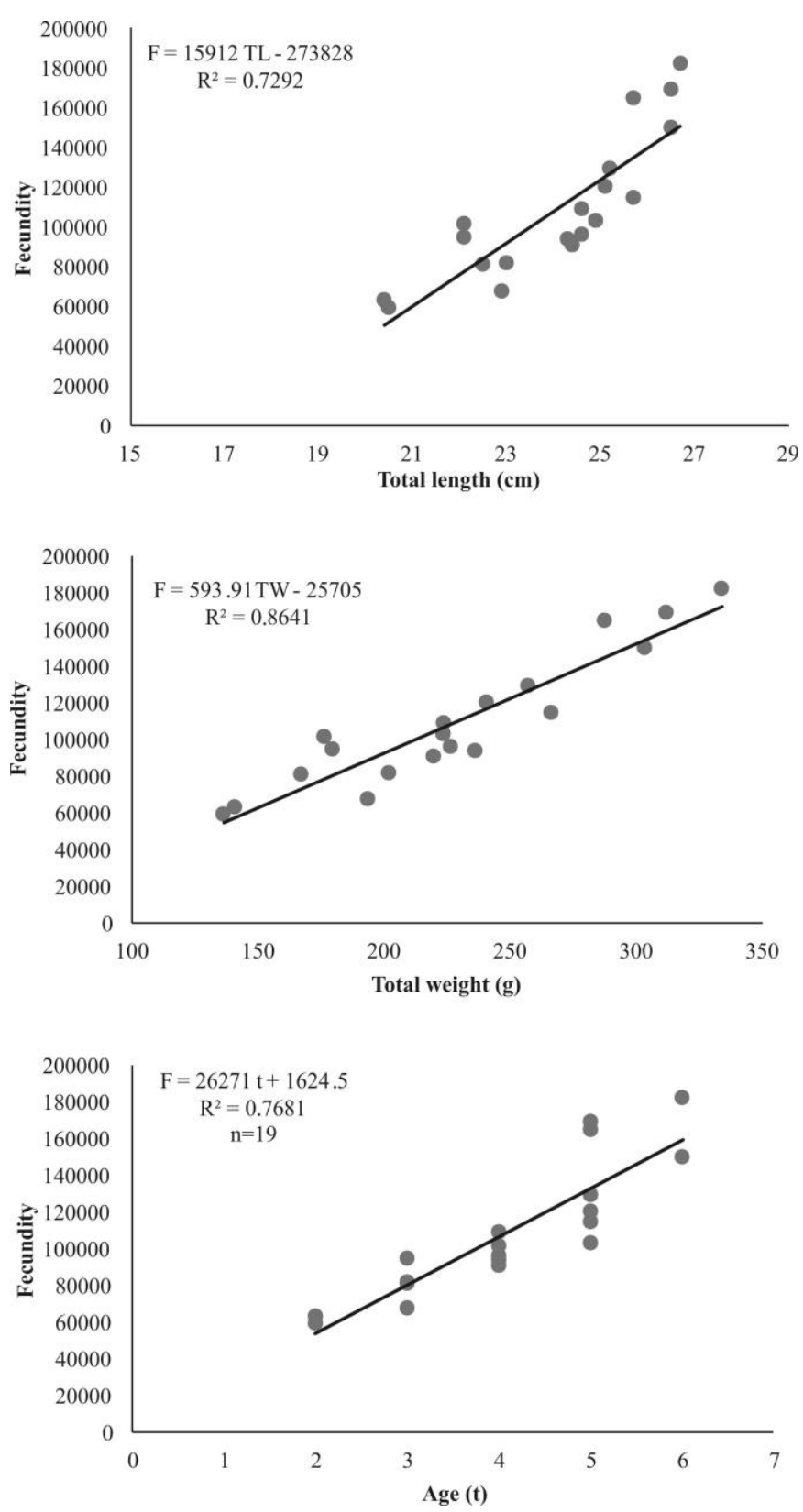

Figure 9. Fecundity-length, fecundity-weight and fecundity-age relationship of the Black Seabream, Spondyliosoma cantharus

Table 1. The length - weight relationship parameters of the Black Seabream, Spondyliosoma cantharus.

\begin{tabular}{lcccccccccc}
\hline & $\begin{array}{c}\text { Number of } \\
\text { Specimen }(\mathrm{n})\end{array}$ & $\mathrm{a}$ & \multicolumn{2}{c}{$\% 95 \mathrm{Cl} \mathrm{a}$} & $\mathrm{b}$ & \multicolumn{2}{c}{$\% 95 \mathrm{Cl} b$} & $\mathrm{~F}$ & $\mathrm{r}^{2}$ & Growth \\
\hline Female & 272 & 0.0145 & 0.0118 & 0.0179 & 3.0075 & 2.941 & 3.074 & 7922.5 & 0.97 & $\mathrm{I}$ \\
Male & 78 & 0.0102 & 0.0058 & 0.0177 & 3.1273 & 2.955 & 3.299 & 1307.3 & 0.95 & $\mathrm{~A}(+)$ \\
All individuals & 355 & 0.0123 & 0.0103 & 0.0149 & 3.0614 & 3.003 & 3.120 & 10577.5 & 0.97 & $\mathrm{~A}(+)$ \\
\hline
\end{tabular}


Mediterranean is stated to be one of the most unproductive areas in the world (Isari et al., 2008), the northeastern part of the Aegean Sea is considered to be the most productive area due to proximity with the Dardanelles, which enriches the area with discharge of low saline and temperate waters from the Black Sea. Isometric growth was detected in many studies for females due to the fact that they use most of their energy for reproductive activity.

As seen in Table 4, the growth coefficient in most studies was low, with the exception of the study conducted around the Gulf of Annaba (Boughamou et al., 2015). The $K$ value of Boughamou et al. (2015) was relatively different from the studies conducted in nearby areas (Mouine-Oueslati et al., 2015; Bradai et al., 1998). Thus, it can be said that black seabream is a slowgrowing fish species. According to age-length data from previous studies, 8 years maximum age with $32.1 \mathrm{~cm} \mathrm{TL}$ in the present study coincided with most other studies. Among all studies, the findings of Neves et al. (2017) were distinctly different from others. This difference may be related to the aging method or inability to distinguish false rings arising from older ages. The asymptotic length $\left(L_{\infty}\right)$ was found to be slightly higher $(33.2 \mathrm{~cm} \mathrm{TL})$ than the maximum length $(32.1 \mathrm{~cm} \mathrm{TL})$ in the present work. The asymptotic length $\left(L_{\infty}\right)$ calculated in this study was slightly lower, whereas the growth performance index was more similar compared to those from other areas (Table 4). This difference may be due to the lack of larger individuals and size range of the sampled fish (Mouine et al., 2010). The results for total mortality rates are consistent with the findings of Neves et al. (2017), and lower than the findings of Pajuelo and Lorenzo (1999). This may be related with varied fishing efforts between the areas due to different fishing mortality rates occurred. If considered specifically, the number of fishing vessels using handline and longline around the Turkish coasts of the North Aegean Sea may be less than other regions, especially the western Mediterranean and the Canary Islands. The fishing effort mostly focuses on gillnets and bottom trawl in the area. Thus, limited fishing pressure may have contributed to this result.

Table 5 shows that the sex ratio was relatively higher in favour of females in most of the studies. The biggest difference between the sexes was found by Mouine et al. (2011) as 22:1 (female:male) among the previous studies. The authors found that the sex ratio became equal after than $27 \mathrm{~cm} \mathrm{TL}$, which represented with only $5.5 \%$ of the total number of individuals. This may be a result of proterogynous hermaphroditism (Bauchot \& Hureau, 1986). The differences in ratio between sexes is mostly related to the length interval of the data set. Sex inversion was found at $24 \mathrm{~cm}$ TL by Gonçalves \& Erzini (2000), Balgueras et al. (1993) and in this study. However, Mouine et al. (2011) detected this value as $18.8 \mathrm{~cm} \mathrm{TL}$, in a data set comprising mostly smaller individuals. Although it seems like a handicap to have a small number of individuals from the largest size group in the data set of this study for determining the length where the sex becomes completely male, similar results were seen in previous studies in which larger individuals were included, confirming the finding that the stock becomes completely male after $32 \mathrm{~cm}$ TL.

Between all previous results on species biology, the most similar findings were determined in terms of spawning season. Almost all studies mentioned that spawning occurred between February and May, peaking from March to April (Table 5). Spawning occurred earlier only in a single study conducted around the Canary

Table 2. Age - length key of the Black Seabream, Spondyliosoma cantharus. (I: Immature, F: Female, M: Male)

\begin{tabular}{|c|c|c|c|c|c|c|c|c|c|c|c|c|c|c|c|c|c|c|c|c|}
\hline & \multicolumn{20}{|c|}{ Age $(t)$} \\
\hline & 0 & & & 1 & & & 2 & & 3 & & 4 & & 5 & & 6 & & 7 & & 8 & \\
\hline Length (TL) & I & $\mathrm{F}$ & $M$ & 1 & $\mathrm{~F}$ & M & $\mathrm{F}$ & M & $\mathrm{F}$ & M & $\mathrm{F}$ & $M$ & $\mathrm{~F}$ & $M$ & $\mathrm{~F}$ & M & $\mathrm{F}$ & $M$ & $\mathrm{~F}$ & M \\
\hline 11 & 2 & & & & & & & & & & & & & & & & & & & \\
\hline 12 & & & & 3 & 3 & & 1 & & & & & & & & & & & & & \\
\hline 13 & & & & & 5 & 1 & & & & & & & & & & & & & & \\
\hline 14 & & & & & 5 & 1 & 2 & & & & & & & & & & & & & \\
\hline 15 & & & & & 2 & & & & & & & & & & & & & & & \\
\hline 16 & & & & & 1 & & & 1 & & & & & & & & & & & & \\
\hline 17 & & & & & 1 & & 2 & & & & & & & & & & & & & \\
\hline 18 & & & & & & & 6 & & 1 & & & & & & & & & & & \\
\hline 19 & & & & & & & 8 & 1 & 7 & & & & & & & & & & & \\
\hline 20 & & & & & & & 10 & 2 & 17 & 1 & & & & & & & & & & \\
\hline 21 & & & & & & & 7 & & 20 & 3 & 5 & & & & & & & & & \\
\hline 22 & & & & & & & & & 19 & 6 & 15 & 2 & 2 & & & & & & & \\
\hline 23 & & & & & & & & & 9 & 4 & 16 & 4 & 4 & 1 & & & & & & \\
\hline 24 & & & & & & & & & & & 16 & 2 & 24 & 5 & & 1 & & & & \\
\hline 25 & & & & & & & & & & & 4 & & 13 & 2 & 7 & 4 & & 1 & & \\
\hline 26 & & & & & & & & & & & & & 6 & 6 & 8 & 4 & 2 & 1 & & \\
\hline 27 & & & & & & & & & & & & & 1 & 1 & 8 & 2 & 3 & 5 & & \\
\hline 28 & & & & & & & & & & & & & & & 1 & 1 & 4 & 4 & 1 & 2 \\
\hline 29 & & & & & & & & & & & & & & & 2 & 1 & & 4 & & \\
\hline 30 & & & & & & & & & & & & & & & & & 1 & 1 & & 1 \\
\hline 31 & & & & & & & & & & & & & & & & & 1 & 1 & 2 & \\
\hline 32 & & & & & & & & & & & & & & & & & & & & 2 \\
\hline Total & 2 & & & 22 & & & 40 & & 87 & & 64 & & 65 & & 39 & & 28 & & 8 & \\
\hline
\end{tabular}


Table 3. Comparision of length-weight relationship of Black Seabream with previous studies.

\begin{tabular}{|c|c|c|c|c|c|c|c|c|c|c|}
\hline Authors & Year & Region & Sex & $\mathrm{N}$ & $\begin{array}{l}\text { Length } \\
\text { Interval } \\
\text { (TL;cm) }\end{array}$ & $\begin{array}{c}\text { Weight } \\
\text { Interval (g) }\end{array}$ & $\mathrm{a}$ & $\mathrm{b}$ & $r^{2}$ & Growth \\
\hline Karakulak et al. & 2006 & $\begin{array}{l}\text { North-eastern } \\
\text { Aegean Sea }\end{array}$ & Both & 46 & $8.2-28.7$ & & 0.0192 & 2.87 & 0.89 & 1 \\
\hline Crec'hriou et al. & 2012 & $\begin{array}{c}\text { French Catalan } \\
\text { Coast }\end{array}$ & Both & 18 & $19.0-45.0$ & $125-1845$ & 0.010 & 3.20 & 0.95 & $*$ \\
\hline \multirow{2}{*}{$\begin{array}{l}\text { Kapiris \& } \\
\text { Klaoudatos }\end{array}$} & \multirow[b]{2}{*}{2011} & \multirow[b]{2}{*}{ Central Aegean Sea } & $\mathrm{F}$ & 12 & $13.8-17.1$ & $40-79$ & 0.00002 & 2.94 & 0.96 & $*$ \\
\hline & & & $\begin{array}{c}\text { M } \\
\text { Both }\end{array}$ & $\begin{array}{l}24 \\
36\end{array}$ & $\begin{array}{l}13.3-15.2 \\
12.7-15.4\end{array}$ & $\begin{array}{l}37-56 \\
37-79\end{array}$ & $\begin{array}{c}0.000005 \\
0.00001\end{array}$ & $\begin{array}{c}3.20 \\
3.0\end{array}$ & $\begin{array}{l}0.98 \\
0.96\end{array}$ & $\underset{1}{A(+)}$ \\
\hline Cengiz & 2013 & $\begin{array}{l}\text { Gallipoli Peninsula } \\
\text { \&Dardanelles }\end{array}$ & Both & 156 & $9.4-31.7$ & $13-659$ & 0.0083 & 3.26 & 0.97 & $A(+)$ \\
\hline Cengiz & 2021 & $\begin{array}{c}\text { Northern Aegean } \\
\text { Sea }\end{array}$ & Both & 31 & $20.0-41.0$ & $125-1050$ & 0.0263 & 2.82 & 0.95 & $A(-)$ \\
\hline \multirow{3}{*}{$\begin{array}{l}\text { Pajuelo \& } \\
\text { Lorenzo }\end{array}$} & \multirow{3}{*}{1999} & \multirow{3}{*}{$\begin{array}{l}\text { Canary Island, } \\
\text { Atlantic }\end{array}$} & $\mathrm{F}$ & 608 & $12.0-40.0$ & $*$ & 0.00714 & 3.25 & 0.97 & $A(+)$ \\
\hline & & & M & 278 & $18.0-40.0$ & $*$ & 0.00556 & 3.34 & 0.96 & $A(+)$ \\
\hline & & & Both & $\begin{array}{c}127 \\
6\end{array}$ & $12.0-40.0$ & $*$ & 0.00732 & 3.25 & 0.99 & $A(+)$ \\
\hline \multirow{3}{*}{$\begin{array}{l}\text { Mouine-Oueslati } \\
\text { et al. }\end{array}$} & \multirow{3}{*}{2015} & \multirow{3}{*}{ Gulf of Tunis } & $\mathrm{F}$ & 330 & $13.4-31.6$ & $39-564$ & 0.012 & 3.09 & 0.99 & 1 \\
\hline & & & $\mathrm{M}$ & 15 & $16.0-36.6$ & $72-806$ & 0.012 & 3.09 & 0.98 & $A(+)$ \\
\hline & & & Both & 369 & $13.4-36.6$ & $39-806$ & 0.012 & 3.10 & 0.99 & $A(+)$ \\
\hline \multirow{3}{*}{$\begin{array}{l}\text { Karachle\&Stergio } \\
\text { u }\end{array}$} & \multirow{3}{*}{2008} & \multirow{3}{*}{ North Aegean Sea } & $\mathrm{F}$ & 40 & $9.7-14.0$ & $*$ & 0.0240 & 2.83 & 0.96 & $*$ \\
\hline & & & $\mathrm{M}$ & 42 & $9.8-13.5$ & $*$ & 0.0216 & 2.88 & 0.97 & $*$ \\
\hline & & & Both & 82 & $9.7-14.0$ & $*$ & 0.0224 & 2.86 & 0.97 & $*$ \\
\hline Özaydın et al. & 2007 & $\begin{array}{c}\text { İzmir Bay, Aegean } \\
\text { Sea }\end{array}$ & Both & 66 & $\begin{array}{l}8.4-18.5 \\
\quad(F L)\end{array}$ & $*$ & 0.0192 & 3.05 & 0.99 & $*$ \\
\hline $\begin{array}{l}\text { Boughamou et } \\
\text { al. }\end{array}$ & 2015 & $\begin{array}{l}\text { Gulf of Annaba } \\
\text { (Algeria) }\end{array}$ & Both & 501 & $13.4-40.0$ & $36-1080$ & 0.000044 & 3.23 & 0.96 & $A(+)$ \\
\hline Espino et al. & 2016 & Canary Islands & Both & 174 & $1.0-25.0$ & $*$ & 0.0120 & 3.09 & 0.99 & $A(+)$ \\
\hline \multirow[t]{2}{*}{$\begin{array}{l}\text { Dimitriadis\& } \\
\text { Fournari- } \\
\text { Konstantinidou }\end{array}$} & 2018 & $\begin{array}{l}\text { Southern lonian } \\
\text { Sea }\end{array}$ & Both & 101 & $11.0-36.0$ & $20-710$ & 0.014 & 3.03 & 0.99 & 1 \\
\hline & & Southern Portugal & Both & 586 & $14.5-34.8$ & $*$ & 0.000020 & 2.95 & 0.96 & \\
\hline Gonçalves et al. & 1997 & $\begin{array}{c}\text { Southwestern } \\
\text { Portugal }\end{array}$ & Both & 886 & $19.0-37.0$ & $*$ & 0.000009 & 3.07 & 0.88 & \\
\hline \multirow[t]{3}{*}{ Neves et al. } & 2017 & Peniche, Portugal & Both & 758 & $2.6-38.0$ & $0.19-841$ & 0.0073 & 3.19 & 0.99 & $A(+)$ \\
\hline & & & $\mathrm{F}$ & 272 & $11.2-31.4$ & $11-614$ & 0.01372 & 3.02 & 0.90 & 1 \\
\hline & & North Aegean Sea & M & 78 & $13.7-32.1$ & $11-431$ & 0.01017 & 3.13 & 0.95 & $A(+)$ \\
\hline This Study & 2021 & & Both & 355 & $11.2-32.1$ & $39-614$ & 0.01171 & 3.08 & 0.92 & $A(+)$ \\
\hline
\end{tabular}

Table 4. Comparison of population parameters of the Black Seabream with previous studies.

\begin{tabular}{|c|c|c|c|c|c|c|c|c|c|c|c|c|}
\hline Researcher & Region & Method & $\mathrm{n}$ & $\begin{array}{l}\text { Length Interval } \\
\text { (TL;cm) }\end{array}$ & Z & $\mathrm{F}$ & $M$ & $\begin{array}{c}\text { Max } \\
\text { Age (t) }\end{array}$ & $\begin{array}{l}\mathrm{L}_{\infty} \\
(\mathrm{cm})\end{array}$ & $\begin{array}{c}\mathrm{K} \\
\left(\text { year }^{-1}\right)\end{array}$ & $t_{0}$ & $\begin{array}{c}\text { Phi } \\
\text { Prime } \\
(\varphi)\end{array}$ \\
\hline $\begin{array}{l}\text { Pajuelo \& Lorenzo } \\
\text { (1999) }\end{array}$ & Canary Island & Otolith & 1272 & $8.0-40.0$ & 1.36 & 0.84 & 0.52 & 10 & 43.35 & 0.24 & -0.11 & 2.65 \\
\hline $\begin{array}{l}\text { Mouine-Oueslati et } \\
\text { al. (2015) }\end{array}$ & Gulf of Tunis & Otolith & 366 & $13.4-36.6$ & $*$ & $*$ & $*$ & 10 & 38.61 & 0.10 & -1.14 & 2.17 \\
\hline $\begin{array}{l}\text { Dulcic \& Kraljevic } \\
\text { (1996) }\end{array}$ & Adriatic & Scale & 745 & $6.2-46.5$ & $*$ & $*$ & $*$ & 14 & 47.70 & 0.18 & -0.27 & 2.61 \\
\hline Neves et al. (2017) & $\begin{array}{l}\text { Peniche, } \\
\text { Portugal }\end{array}$ & Otolith & 535 & $2.8-38.0$ & 0.65 & 0.37 & 0.28 & 17 & 40.66 & 0.12 & -1.26 & 2.40 \\
\hline $\begin{array}{l}\text { Boughamou et al. } \\
(2015)\end{array}$ & $\begin{array}{l}\text { Gulf of } \\
\text { Annaba }\end{array}$ & Otolith & 373 & $13.0-36.0$ & $*$ & $*$ & $*$ & 7 & 33.54 & 0.52 & -0.04 & 2.76 \\
\hline Bradai et al. (1998) & Gulf of Gabes & Scale & 109 & $8.3-27.0$ & $*$ & $*$ & $*$ & 6 & 35.73 & 0.14 & -1.42 & 2.26 \\
\hline Abecasis et al. & Southern & Scale & 378 & $5.0-35.0$ & $*$ & $*$ & $*$ & 11 & 34.48 & 0.21 & -1.22 & 2.41 \\
\hline (2008) & Potrugal & Otolith & 905 & $4.0-40.0$ & $*$ & $*$ & $*$ & 13 & 30.32 & 0.26 & -1.20 & 2.37 \\
\hline This Study & $\begin{array}{c}\text { North } \\
\text { Aegean Sea }\end{array}$ & Scale & 355 & $11.2-32.1$ & 0.64 & 0.17 & 0.47 & 8 & 33.21 & 0.21 & -1.84 & 2.37 \\
\hline
\end{tabular}


Table 5. Comparison of reproduction parameters of the Black Seabream with previous studies (F: female, M: male; L50: First sexual maturity length).

\begin{tabular}{|c|c|c|c|c|c|c|}
\hline Researcher & Region & $\begin{array}{l}\text { Sex Ratio } \\
\text { (F/M) }\end{array}$ & Spawning Time & $\begin{array}{c}\text { Peak } \\
\text { Spawning }\end{array}$ & $\mathrm{L}_{50}$ & Fecundity \\
\hline $\begin{array}{l}\text { Pajuelo \& Lorenzo } \\
\text { (1999) }\end{array}$ & Canary Island, Atlantic & $2.18: 1$ & $\begin{array}{l}\text { Autumn - } \\
\text { Spring }\end{array}$ & $\begin{array}{l}\text { January - } \\
\text { February }\end{array}$ & $\begin{array}{l}F=17.3 \\
M=22.7\end{array}$ & $*$ \\
\hline $\begin{array}{l}\text { Boughamou et al. } \\
\text { (2015) }\end{array}$ & Gulf of Annaba (Algeria) & $5.68: 1$ & February-May & April & $\begin{array}{l}F=19.3 \\
M=21.3\end{array}$ & $*$ \\
\hline Mouine et al. (2011) & Gulf of Tunis & $22: 1$ & January -May & March - April & $\mathrm{F}=17.8$ & $*$ \\
\hline $\begin{array}{l}\text { Gonçalves \& Erzini } \\
(2000)\end{array}$ & Portugal & $2.28: 1$ & $\begin{array}{l}\text { February - } \\
\text { April }\end{array}$ & March & $\begin{array}{l}F=19.98 \\
M=22.41\end{array}$ & $\begin{array}{c}37506-112074(\text { Mean=61 } \\
396)\end{array}$ \\
\hline Neves et al. (2018) & Western Portugal & $1.66: 1$ & February - May & March - April & $\mathrm{F}=18.41$ & $\begin{array}{c}5041-95398 \quad(\text { Mean }=42 \\
513)\end{array}$ \\
\hline Dulcic et al. (1998) & Crotian Coasts & & & & & $31670-554070$ \\
\hline Balgueras et al. (1993) & $\begin{array}{c}\text { Saharan Bank, Eastern } \\
\text { Adriatic }\end{array}$ & & & & & $\begin{array}{c}36926-143900(\text { Mean=65 } \\
659)\end{array}$ \\
\hline This Study & North Aegean Sea & $3.49: 1$ & February - May & March - April & $\begin{array}{l}F=20.59 \\
M=22.25\end{array}$ & $\begin{array}{c}59666-182589 \text { (Mean=109 } \\
457)\end{array}$ \\
\hline
\end{tabular}

Islands (Pajuelo \& Lorenzo, 1999). Wootton (1998) reported that the most influential variable on the spawning season of fish is different sea water characteristics between regions. The variation in spawning seasons between the results of Pajuelo \& Lorenzo (1999) and this study may arise due to different water characteristics in the Atlantic and Northeastern Aegean Sea. Such a distinct range of seasonality for spawning was thought to indicate that the species requires very specific conditions for reproduction, especially in terms of water temperature. In the study area, sea surface temperature was measured between 12 and $14.4{ }^{\circ} \mathrm{C}$ (Daban et al., 2020) in March and April, when the spawning of black seabream peaked. The species was observed to spawn during early spring as with many teleost fish distributed in the Mediterranean (Tsikliras et al., 2010). The period of spawning ensures optimum conditions for growth and survival of black seabream in the early life stages; thus, they encounter lower mortality rates in this critical stage (Winemiller \& Rose, 1992). Among Sparidae species, black seabreams were observed to reproduce later than Sparus aurata and Diplodus vulgaris but earlier than Dentex macropthalmus and Pagellus acarne. The reproduction period of the black sea bream coincided with those of Diplodus sargus and Boops boops (Soykan et al., 2015; Mehanna, 2007).

Male black seabream individuals reached first sexual maturity length at a larger size than females. The results of sexual maturity length coincided with the results of the previous studies (Table 5). This situation was reported for some protogynic hermaphrodite Sparidae species such as Dentex macrophthalmus (Soykan et al., 2015) and Pagellus erythrinus (Zarrad et al., 2010; Pajuelo \& Lorenzo, 1998).

The mean absolute fecundity in the present study was higher than the previous studies completed around the eastern Mediterranean (Gonçalves \& Erzini, 2000; Neves et al., 2018; Balgueras et al., 1993). Dulcic et al. (1998) found more total eggs per female $(554,070)$. These differences may stem from the oocyte size threshold; the authors calculated fecundity from 0.20 to
$0.80 \mathrm{~mm}$ oocyte diameter. In the present study, the oocyte size threshold was applied according to Balgueras et al. (1993), which was above $0.50 \mathrm{~mm}$. The comparison of fecundity results $\mathrm{cn}$ between this study and Balgueras et al. (1993) may be more compatible due using similar methods. As in many studies, fecundity increased with the increases in the length, weight and age. Boufekane et al. (2021) revealed the mean absolute fecundity of co-occuring Sparidae species, Diplodus sargus, as $186,570 \pm 5,990$, similar to our study.

\section{Conclusion}

The minimum landing size of black seabream was given as $23 \mathrm{~cm} \mathrm{TL}$, as ruled by Portuguese fishery and northwestern Inshore Fisheries and Conservation Authority. However, no valid data were found in EU technical regulations (Collins \& Mallinson, 2012) and for Turkey. The length at first sexual maturity in the present study was determined as 20.59 and $22.25 \mathrm{~cm}$ TL for females and males, respectively. As seen in Table 5, in order to protect sexually mature males, the minimum landing size must be greater than $23 \mathrm{~cm} \mathrm{TL}$, which is the limit value just above the length at first sexual maturity. Due to male guarding behaviour of fertilized eggs on the nests around shallower (9-23 $\mathrm{m}$ depths) gravel substrates (Collins \& Mallinson, 2012), male individuals are affected most by the fishing effort. In protogynous hermaphrodite species such as black seabream, since all of the larger individuals are male, it poses a negative situation such as sperm limitation (Alonzo \& Mangel, 2004; Neves et al., 2017) in the case of stock collapse. Since longlines and handlines are extensively used in the commercial fishing of the black seabream, the selectivity parameters could be easily arranged in order to avoid catching fish that have not reached sexual maturity. According to purse seine regulations in communique no. 2020/39 on the regulation of commercial fishing in Turkey, purse seine fishing shall be performed deeper than $24 \mathrm{~m}$. This depth may be a potential issue for management implementations due to damage to nesting sites of black seabream. 
The results of the present study revealed the first findings around the eastern Mediterranean, which may be useful for fisheries management authorities and researchers.

\section{Ethical Statement}

Ethics committee certificate was not requested since experimental animals were not used in the study and sampling was made in the form of dead fish from the fishermen.

\section{Funding Information}

This work was supported by the Scientific Research Projects Coordination Unit of Çanakkale Onsekiz Mart University, Project number: FBA-2020-3295.

\section{Author Contribution}

This article was written by a single author.

\section{Conflict of Interest}

The author declare that they have no known competing financial or non-financial, professional, or personal conflicts that could have appeared to influence the work reported in this paper.

\section{Acknowledgements}

The authors thank Gençtan Erman Uğur and Buminhan Burkay Selçuk for their valuable help during the laboratory study. This work was supported by the Scientific Research Projects Coordination Unit of Çanakkale Onsekiz Mart University, Project number: FBA-2020-3295.

\section{References}

Abecasis, D., Bentes, L., Coelho, R, Correia, C., Lino, P.G., Monteiro, P., Goncalves J.M.S., Ribeiro, J., \& Erzini, K. (2008). Ageing seabreams: a compara-tive study between scales and otoliths. Fisheries Research, 89, 3748. https://doi.org/10.1016/j.fishres.2007.08.013

Ak, O., Kutlu, S., \& Aydın, í. (2008). An Investıgatıon on Fish Fauna by Bottom Trawled in Trabzon Coast (East Black Sea). Erciyes University Journal of the Institute of Science and Technology, 24(1-2), 380-388 (in Turkish).

Ak, O., Kutlu, S., \& Aydın, İ. (2011). Distribition of demersal species and density of the economic fishes in the coastal Trabzon. Journal of Fisheries Sciences, 5(2), 99-106 (in Turkish).

Alonzo, S.H., \& Mangel, M. (2004). The effects of size-selective fisheries on the stock dynamics of and sperm limitation in sex changing fish: California sheephead (Semicossyphus pulcher) as an illustrative example. Fishery Bulletin, 102, 1-13.

Bagenal T.B. (1978). Aspects of Fish Fecundity. In S.D. Gerking (Eds.), Ecology of Freshwater Fish Production (pp. 75101). Oxford: Blackwell Scientific Publications.
Balguerías, E., Quintero, M.E., \& González, J.F. (1993). Características reproductivas de la chopa, Spondyliosoma cantharus (Linnaeus, 1758) del Banco Sahariano. Boletín del Instituto Español de Oceanografía, 9(1), 185-201.

Başusta, N., \& Erdem, Ü. (2000). A Study on the Pelagic and Demersal Fishes of İskenderun Bay. Turkish Journal of Zoology, 24, 1-19 (in Turkish).

Bauchot, M.L., \& Hureau, J.C. (1986). Sparidae. In P.J.P. Whitehead, M.L. Bauchot, J.C. Hureau, J. Nielsen \& E. Tortonese (Eds.), Fishes of the north-eastern Atlantic and the Mediterranean (pp. 883-907). UNESCO, Paris.

Bauchot, M.L., \& Hureau, J.C. (1990). Sparidae. In J.C. Quero, J.C. Hureau, C. Karrer, A. Post \& L. Saldanha (Eds.), Checklist of the fishes of the eastern tropical Atlantic (CLOFETA) (pp. 790-812). JNICT, Lisbon, SEI, Paris, \& UNESCO, Paris.

Bingel, F. (2002). Identification of Fish Populations. Icel: Baki Press.

Boufekane, B., Chakroun-Marzouk, N., Kelai, E., Alioua, Z., Amira, S., \& Harchouche, K. (2021). Reproductive Traits and Somatic Growth of Diplodus sargus sargus (Linnaeus, 1758) in the Central Algerian Coast (Southern Mediterranean Sea). Turkish Journal of Fisheries and Aquatic Sciences, 21, 381-399. http://doi.org/10.4194/1303-2712-v21_8 03

Boughamou, N., Derbal, F., \& Kara, M.H. (2015). Age, growth and reproduction of the black sea bream Spondyliosoma cantharus (Linnaeus, 1758) (Sparidae) in the Gulf of Annaba (Algeria). Journal of Applied Ichthyology, 31, 773-779. https://doi.org/10.1111/jai.12714

Bradai, M.N., Ghorbel, M., Jarboui, O., \& Bouain, A. (1998). Croissance de trois espe'ces de sparide's: Diplodus puntazzo, Diplodus vulgaris et Spondyliosoma cantharus du golfe de Gabe's (Tunisie). In J. Lleonart (Eds.), Dynamique des populations marines (pp. 51-56), CIHEAM, Zaragoza.

Cengiz, Ö., İşmen, A., Özekinci, U., \& Öztekin, A. (2011). An investigation on fish fauna of Saros Bay (Northern Aegean Sea). Afyon Kocatepe University Journal of Sciences, 11(1): 31-37.

Cengiz, Ö., Öztekin, A., \& Özekinci, U. (2012). An investigation on fishes spreading along the coasts of Gallipoli Peninsula and Dardanelles (North-eastern Mediterranean, Turkey). Firat University Journal of Science, 24, 47-55.

Cengiz, Ö. (2013). Length-weight relationships of 22 fish species from the Gallipoli peninsula and Dardanelles (northeastern Mediterranean, Turkey). Turkish Journal of Zoology, 37, 419-422. https://doi.org/10.3906/zoo-1209-30

Cengiz, Ö. (2021). Weight-length relationship and maximum length record of black seabream (Spondyliosoma cantharus Linnaeus, 1758) for entire Aegean Sea and Turkish Waters. Research in Marine Sciences, 6(3), 992 1004.

Cengiz, Ö., \& Paruğ, Ş. (2021). Growth parameters of blotched picarel (Spicara maena Linnaeus, 1758) from Saros Bay (Northern Aegean Sea, Turkey). Acta Natura et Scientia, 2(1), 40-48. https://doi.org/10.29329/actanatsci.2021.314.7

Collins, K.J., \& Mallinson, J.J. (2012). Surveying black bream, Spondyliosoma cantharus (L.), nesting sites using sidescan sonar. Underwater Technology, 30, 183-188. https://doi.org/10.3723/ut.30.183 
Crec'hriou, R., Neveu, R., \& Lenfant, P. (2012). Length-weight relationship of main commercial fishes from the French Catalan coast. Journal of Applied Ichthyology, 28, 861862. https://doi.org/10.1111/j.1439-0426.2012.02030.x

Çoker, T., \& Akyol, O. (2018). An evaluation on the fish diversity of Saroz Bay and Gökçeada Island (Northern Aegean Sea). Turkish Journal of Maritime and Marine Sciences, 4(1), 81-92.

Daban, I. B., Yüksek, A., \& Altın, A. (2020). Spatial and temporal variations of anchovy eggs and larvae, Engraulis encrasicolus (Linnaeus, 1758), around Gökçeada Island, North Aegean Sea. J. Black Sea/Mediterranean Environment, 26, 1, 84-99.

Dimitriadis, C., \& Fournari-Konstantinidou, I. (2018). Lengthweight relations for 20 fish species (Actinopterygii) from the southern Ionian Sea, Greece. Acta Ichthyologica et Piscatoria, 48(4), 415-417. https://doi.org/10.3750/AIEP/02466

Dulcic, J., \& Kraljevic, M. (1996). Growth of the Black Sea Bream Spondyliosoma cantharus (L) in the Eastern Middle Adriatic. Archive of Fishery and Marine Research, 44(3), 279-293.

Dulcic, J., Skakelja, N., Kraljevic, M., \& Cetinic, P. (1998). On the Fecundity of the Black Sea bream, Spondyliosoma cantharus (L.), from the Adriatic Sea (Croatian coast). Scientia Marina, 62(3): 289-294. https://doi.org/10.3989/scimar.1998.62n3289

Eschmeyer's Catalog of Fishes. 2020. Species by family/subfamily in Eschmeyer's Catalog of Fishes (Online version-updated 02 June 2020). URL: http://researcharchive.calacademy.org/research/ ichthyology/catalog/SpeciesByFamily.asp\#Sparidae. $(06 / 2020)$

Eryılmaz, L. (2003). A study on the fishes of Bozcaada Island (North Aegean Sea). Turkish Journal of Marine Science, 9 (2), 121-137.

Espino, F., Triay-Portella, R., González, J.A., Haroun, R., \& Tuya, F. (2016). Length-weight relationships of ten teleost fish species from seagrass meadows at the Canary Islands (North-eastern Atlantic). Cybium, 40, 323-325.

Gayanilo, Jr. F.C., Sparre, P., \& Pauly, D. (2005). FAO-ICLARM Stock Assessment Tools II (FiSAT II). Revised Version. User's Guide. FAO Computerized Information Series (Fisheries) 8: 1-168.

GFCM. (2020). The report of the state of Mediterranean and Black Sea fisheries 2020. General Fisheries Commission for the Mediterranean, Food and Agriculture Organization of the United Nations. https://www.fao.org/3/CB2427EN/CB2427EN.pdf

Gibson, R.N., \& Ezzi, I.A. (1980). The biology of the scaldfish, Arnoglossus laterna (Walbaum) on the west coast of Scotland. Journal of Fish Biology, 17, 565-576. https://doi.org/10.1111/j.1095-8649.1980.tb02788.x

Golani, D., Öztürk, B., \& Başusta, N. (2006). Fishes of the Eastern Mediterranean. Turkish Marine Research Foundation (TÜDAV).

Gonçalves, J.M.S., Bentes, L., Lino, P.G., Ribeiro, J., Canario, A.V.M., \& Erzini, K. (1996). Weight-length relationships for selected fish species of the small-scale demersal fisheries of thesouth and south-west coast of Portugal. Fisheries Research, 30, 253-256. https://doi.org/10.1016/S0165-7836(96)00569-3

Gonçalves, J.M.S., \& Erzini, K. (2000). The Reproductive Biology of Spondyliosoma cantharus (L.) from the SW Coast of Portugal. Scienta Marina, 64(4), 403-411. https://doi.org/10.3989/scimar.2000.64n4403

Gönener, S., \& Özdemir, S. (2012). Investigation of the interaction between bottom gillnet fishery (Sinop, Black Sea) and bottlenose dolphins (Tursiops truncatus) in terms of economy. Turkish Journal of Fisheries and Aquatic Sciences, 12, 115-126. https://doi.org/10.4194/1303-2712-v12_1_14

Gönülal, O., \& Güreşen, S.O. (2014). A list of macrofauna on the continental shelf of Gökçeada Island (northern Aegean Sea) with a new record (Gryphus vitreus Born, 1778) (Brachiopoda, Rhynchonellata) for the Turkish seas. J. Black Sea/Medit Environ., 20, 228-252.

Heemstra, P.C. (1995). Additions and corrections for the 1995 impression. In M.M. Smith \& P.C. Heemstra (Eds.), Revised Edition of Smiths' Sea Fishes. (pp. 5-15). Springer-Verlag, Berlin.

IUCN. (2020). The IUCN Red List of Threatened Species. Version 2020-2. Downloaded 16 July 2020.

Isari, S., Fragopoulu, N., \& Somarakis, S. (2008). Interanual variability in horizontal patterns of larval fish assemblages in the northeastern Aegean Sea (eastern Mediterranean) during early summer. Estuarine, Coastal and Shelf Science, 79, 607-619. https://doi:10.1016/j.ecss.2008.06.001

Kapiris, K., \& Klaoudatos, D. (2011). Length-weight relationships for 21 fish species caught in the Argolikos Gulf (central Aegean Sea, eastern Mediterranean). Turk. J. Zool., 35(5), 717-723. https://doi.org/10.3906/zoo-1003-122

Karachle, P.K., \& Stergiou, K.I. (2008). Length-length and length-weigh relationships of several fish species from the North Aegean Sea (Greece). Journal of Biological Research, 10, 149-157.

Karakulak, F.S., Erk, H., \& Bilgin, B. (2006). Length-weight relationships for 47 coastal fish species from the northern Aegean Sea, Turkey. Journal of Applied Ichthyology, 22, 274-278. https://doi.org/10.1111/j.1439-0426.2006.00736.x

Keskin, Ç., \& Ünsal, N. (1998). The fishfauna of Gökçeada Island, NE Aegean Sea, Turkey. Italian Journal of Zoology, 65, 299-302. https://doi.org/10.1080/11250009809386836

Keskin, Ç. (2010). A review of fish fauna in the Turkish Black Sea. Journal of the Black Sea/Mediterranean Environment, 16(2), 195-210.

Keskin, Ç., Turan, C., \& Ergüden, D. (2011). Distribution of the demersalfishes on the continental shelves of the Levantine and North Aegean Seas (Eastern Mediterranean). Turkish Journal of Fisheries and Aquatic Sciences, 11(3), 413-423. https://doi.org/10.4194/trjfas.2011.0311

King, M. (1995). Reproduction and recruitment. In M. King (Eds.), Fisheries biology, assessment and management (pp. 151-165). Fishing New Books:Oxford.

Marshall, T.M. (2009). Implementing information on stock reproductive potential in fisheries management: the motivation, challenges and opportunities. In T. Jakobsen, M.J. Fogarty, B.A. Megrey \& E. Moksness (Eds.), Fish reproductive biology (pp. 395-420). Wiley-Blackwell Scientific Publications, UK.

Mater, S., Kaya, M., \& Bilecenoğlu, M. (2011). Marine Fish Atlas of Turkey (4th ed). Ege University Press (in Turkish).

Mehanna, S.F. (2007). A preliminary assessment and management of gilthead breamSparus auratain the Port Saidfishery, the Southeastern Mediterranean, Egypt. 
Turkish Journal of Fisheries and Aquatic Sciences, 7, 123130.

Mouine, N., Ktari, M.H., \& Chakroun-Marzouk, N. (2011). Reproductive characteristics of Spondyliosoma cantharus (Linnaeus, 1758) in the Gulf of Tunis. Journal of Applied Ichthyology, 27, 827-831. https://doi.org/10.1111/j.1439-0426.2010.01518.x

Mouine-Oueslati, N., Ahlem, R., Ines, C., Ktari, M.H., \& Chakroun-Marzouk, N. (2015). Age and growth of Spondyliosoma cantharus (Sparidae) in the Gulf of Tunis. Scientia Marina, 79(3), 319-324.

https://doi.org/10.3989/scimar.04176.19B

Nelson, J.S. (2006). Fishes of the World (4th ed). John Wiley \& Sons, Inc.

Neves, A., Vieira, A.R., Sequeira, V., Paiva, R.B., \& Gordo, L.S. (2017). Modelling the growth of a protogynous sparid species, Spondyliosoma cantharus (Teleostei: Sparidae). Hydrobiologia, 797, 265-275. https://doi.org/10.1007/s10750-017-3188-1

Neves, A., Vieira, A.R., Sequeira, V., Paiva, R.B., \& Gordo, L.S. (2018). Insight on re-productive strategy in Portuguese waters of a commercial protogynous species, the black seabream Spondyliosoma cantharus (Sparidae). Fisheries Research, 206, 85-95. https://doi.org/10.1016/j.fishres.2018.05.004

Nieto, A., Ralph, G.M., Comeros-Raynal, M.T., Kemp, J., García Criado, M., Allen, D.J., Dulvy, N.K., Walls, R.H.L., Russell, B., Pollard, D., García, S., Craig, M., Collette, B.B., Pollom, R., Biscoito, M., Labbish Chao, N., Abella, A., Afonso, P., Álvarez, H., ... Williams, J.T. (2015). European Red List of marine fishes. Publications Office of the European Union: Luxembourg.

O'Brien, C.M. (2009). Management: New approaches to old problems. In T. Jakobsen, M.J. Fogarty, B.A. Megrey \& E. Moksness (Eds.), Fish reproductive biology (pp. 355-395). Wiley-Blackwell Scientific Publications.

Özaydin, O., Uçkun, D., Akalın, S., Leblebici S., \& Tosunoğlu, Z. (2007). Length-weight relationships of fishes captured from Izmir Bay, Central Aegean Sea. Journal of Applied Ichthyology, 23, 695-696. https://doi.org/10.1111/j.1439-0426.2007.00853.x

Pajuelo, J.G., \& Lorenzo, J.M. (1999). Life history of black seabream, Spondyliosoma cantharus, off the Canary Islands, Central-east Atlantic. Environmental Biology of Fishes, 54(3), 325-336. https://doi.org/10.1023/A:1007515301745

Paruğ, Ş., \& Cengiz, Ö. (2020). The maximum length record of the Blackspot seabream (Pagellus bogaraveo Brünnich, 1768) for the Entire Agean Sea and Turkish Territorial Waters. Turkish Journal of Agriculture-Food Science and Technology, 8(10), 2125-2130.

https://doi.org/10.24925/turjaf. v8i10.2125-2130.3597

Pauly, D. (1984). Fish population dynamics in tropical waters: a manual for use with programmable calculators. ICLARM Stud Rev.

Pauly D., \& Munro J.I. (1984). Once more on the comparision of growth in fish and invertebrates. Fishbyte.

Riede, K. (2004). Global register of migratory species - from global to regional scales. Final Report of the R\&D-Projekt 80805 081. Federal Agency for Nature Conservation, Bonn, Germany. 329 p.

Saad, A. (2005). Check list of bony fishes collected from the coast of Syria. Turkish Journal of Fisheries and Aquatic Science, 5(2), 99-106.

Santini, F., Carnevale, G., \& Sorenson, L. (2014). First multilocus timetree of seabreams and porgies (Percomorpha: Sparidae). Italian Journal of Zoology, 81(1), 55-71. https://doi.org/10.1080/11250003.2013.878960

Shapiro, D.Y. (1984). Sex Reversal and Sociodemographic Processes in Coral Reef Fishes. In: G.W. Potts \& R.J. Wootton (Eds.), Fish Reproduction: Strategies and Tactics (pp. 103-117). Academic Press Limited, London.

Soykan, O., İlkyaz, A.T., Metin, G., \& Kınacıgil, H.T. (2015). Growth and reproduction of Boops boops, Dentex macrophthalmus, Diplodus vulgaris and Pagellus acarne (Actinopterygii: Perciformes: Sparidae) from east-central Aegean Sea, Turkey. Acta Ichthyologica et Piscatoria, 45 39-55. https://doi.org/10.3750/AIP2015.45.1.05

Torcu, H., \& Aka, Z. (2000). A study on the fishes of Edremit Bay. Turkish Journal of Zoology, 24, 45-61.

Türkoğlu, M. (2010). Temporal variations of surface phytoplankton, nutrients and chlorophyll $a$ in the Dardanelles (Turkish Straits System): a coastal station sample in weekly time intervals. Turkish Journal of Biology, 34, 319-333. https://doi.org/10.3906/biy-081017

Tsikliras, C.A., Antonopoulou, E., \& Stergiou, I.K. (2010). Spawning period of Mediterranean marine fishes. Reviews in Fish Biology and Fisheries, 20, 499-538. https://doi.org/10.1007/s11160-010-9158-6

Winemiller, K.O., \& Rose, K.A. (1992). Patterns of life-history diversification in North American fishes: implications for population regulation. Canadian Journal of Fisheries and Aquatic Sciences, 49, 2196-2218. https://doi.org/10.1139/f92-242

Yıldız, T., Zengin, M., Uzer, U., Karakulak, F.S., Akpınar, i.Ö. (2019). Community structure of demersal assemblages in the southwestern Black Sea. Regional Studies in Marine Science. 32, 100844.

Zarrad, R., Cherif, M., Gharbi, H., Jarboui, O., \& Missaoui, H. (2010). Reproductive cycle and sex reversal of Pagellus erythrinus (Linnaeus, 1758) in the gulf of Tunis (central Mediterranean). Bulletin De L'institut National Des Sciences et Technologies de la Mer de Salammbô, 37, 1320. 